\title{
LITHOSTRATIGRAPHY OF THE MALIGÂT AND HAREØEN FORMATIONS, WEST GREENLAND BASALT GROUP, ON HARE $\emptyset E N$ AND WESTERN NÛGSSUAQ
}

\author{
Niels Hald \\ Introduction
}

The Early Tertiary lavas in West Greenland have been divided into three lithostratigraphical units by Hald \& Pedersen (1975). They comprise from below the Vaigat Formation consisting of lavas and pillow breccias, mostly of tholeiitic olivine basaltic or picrite basaltic composition; the Maligât Formation dominated by plagioclase porphyritic, tholeiitic basalts, and the Hareøen Formation consisting of olivine porphyritic, transitional basalts. Apart from volcanic rocks the three formations contain several sequences of clastic sedimentary rocks.

The type areas of the Maligât and Hareøen Formations are western Nûgssuaq and Hareøen respectively.

A subdivision of the two younger formations in these areas is presented below.

The geology of the Tertiary igneous rocks has been summarised by Munck \& NoeNygaard (1957), Rosenkrantz \& Pulvertaft (1969) and Clarke \& Pedersen (1976). Henderson (1969). Münther (1973), Pedersen (1970) and Hald (1973; 1976) have all contributed to the geological description of western Nûgssuaq and Hareøen. Geological maps (1:100 000) including western Nûgssuaq and Hareøen have been compiled by GGU (sheets Agatdal 70 V.1 $\mathrm{N}$ and Qutdligssat $70 \mathrm{V.1}$ S).

\section{Lithostratigraphy \\ Maligât Formation (Hald \& Pedersen, 1975)}

The formation is here divided into three members from below in ascending order: Nûluk Member, Ifsorisok Member and Kanísut Member (fig. 3).

Nûluk Member

new member

Henderson (1969) and Münther (1973) have recognised the oldest lavas of the Maligât Formation in western Nûgssuaq as a special lithological unit. 


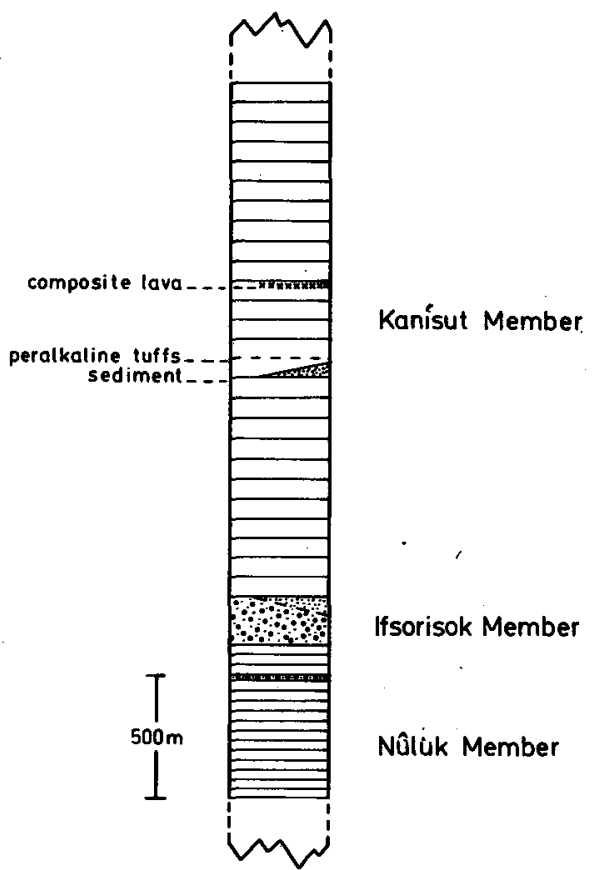

Fig. 3. Type section for the Maligât Formation in Western Núgssuaq.

\section{Name}

From Nûluk, a small point on the north coast of western Nûgssuaq $14 \mathrm{~km}$ west-northwest of the village of Niaqornat (see map in Hald, 1976).

\section{Type section}

North coast of western Nûgssuaq between $10.5 \mathrm{~km}$ and $15 \mathrm{~km}$ west-north-west of Niaqornat. The type section is cut by many faults. The upper boundary is seen west of Nûluk; because of faulting the lower boundary is not exposed.

\section{Thickness}

The maximum exposed thickness of the member - $750 \mathrm{~m}$ - is found along the north coast of western Nûgssuaq. Because of faulting the thickness has not been evaluated on Hareøen.

\section{Lithology}

The member is characterised by tholeitic flows generally $5-10 \mathrm{~m}$ thick with a yellowbrown weathering. The flows are usually as lavas with a thin layer of scoria; plagioclase is 
the dominant phenocryst mineral. Chemically the tholeitic lavas are characterised by low content of potassium (generally $0.15-0.30 \%$ ). Isolated flows of olivine porphyritic picrite basalt similar to the dominant lava type in the Vaigat Formation are found in a few places.

On Nûgssuaq layers of coarse grained basaltic talus sediments are intercalated with the lavas in the upper part of the member. On Hareøen a tuffaceous layer is seen $250 \mathrm{~m}$ below the top of the member.

\section{Boundaries}

The contact with the older Vaigat Formation is faulted everywhere on western Nûgssuaq and Hareqen.

On western Nûgssuaq the upper boundary is well exposed on the north coast west of Nûluk where the member is concordantly overlain by sediments belonging to the Ifsorisok Member. Around Kugssinínguaq at the south coast lavas alternate for approximately $100 \mathrm{~m}$ with sediments typical of the Ifsorisok Member, and the upper boundary of the Nûluk Member is defined where the sediments become dominant. Along the west side of Kûp qôrorssua the Ifsorisok Member rests with an angular unconformity on the Nûluk Member.

On Hareøen the Nûluk Member is overlain conformably by lavas belonging to the Kanísut Member.

\section{Distribution}

On western Nûgssuaq the member crops out in various fault-bounded areas: along the north coast between Nûluk and Sangmissoq; along the west side of the Itivdle valley between the north coast and Ivssorigsoq and between Qagdlusssat and the south coast. Furthermore the member is exposed in the Kugssinínguaq area at the south coast.

Also on Hareøen the member crops out in a number of fault bounded areas: along the south west coast between Talerua and Kugssinêraq and on the north-east coast at Silasiornerdlungnartoq and north-west of Talerua (fig. 4).

\section{Ifsorisok Member \\ (redefined)}

Interbasaltic sediments from the south coast of western Nûgssuaq and from the west side of Itivdle valley were included in the Ifsorisoklagren (Ifsorisok layers) by Nordenskiöld (1871). According to Koch (1963) the Ifsorisok Formation consists of sediments which are intercalated in the younger, plagioclase porphyritic basalts on Hareøen and western Nûgssuaq. The Ifsorisok Member is here redefined to comprise only the sedimentary rocks found between the Nûluk and Kanísut Members. The sediments described by Nordenskiöld from western Nûgssuaq belong to the redefined Ifsorisok Member.

\section{Name}

From the river Ivssorigsoq (the original spelling of Nordenskiöld (1871) is Ifsorisok). 


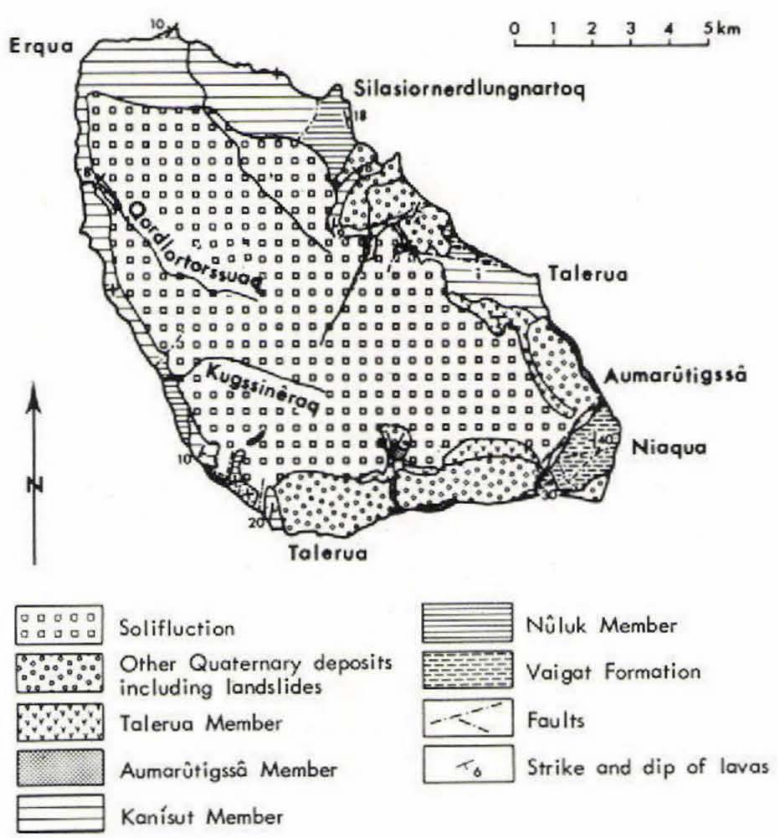

Fig. 4. Geological map of Hareøen.

\section{Type locality}

Ivssorigsoq, western Nûgssuaq.

\section{Reference section}

North coast of Nûgssuaq $16 \mathrm{~km}$ west-north-west of Niaqornat.

\section{Thickness}

The thickness varies from $0 \mathrm{~m}$ to $225 \mathrm{~m}$.

\section{Lithology}

A coarse grained talus breccia is the dominant rock type of the Ifsorisok Member. The breccia consists of angular fragments of basalt up to $0.5 \mathrm{~m}$ in size set in a fine grained matrix. Thin sand beds often with plant remains occur and are well exposed at Kûp qôrorssua, Nûgssuaq. The breccia is locally overlain by several metres of sand, light coloured tuffs, clay-ironstone and coal e.g. at Nûluk on the north coast, along the west side of the Itivdle valley (Ivssorigsoq and Kulelven) and at Kugssinínguaq near the south coast.

The sediments have been intruded by basaltic sills west of Nûluk at the north coast and in the Ivssorigsoq and Kulelven valleys. 


\section{Boundaries}

The boundary with the older Nûluk Member has been described above. The upper boundary is seen in the reference section and in several other places where lavas belonging to the younger Kanísut Member have covered the sediments concordantly or with only a minor angular unconformity.

\section{Distribution}

On western Nôgssuaq the member has the same areal distribution as the Nâluk Member. On Hareøen sediments belonging to the Ifsorisok Member are unknown.

\section{Kanísut Member \\ new member}

\section{Name}

From the small peninsula Kanísut on the north coast of western Nûgssuaq $18 \mathrm{~km}$ westnorth-west of Niaqornat.

\section{Type section}

The type section is composite with the lower part situated on the west side of a valley. 2 km east-south-east of Kanísut and the upper part situated along the west coast of western Nûgssuaq between Nûgssûtâ and Kangeq.

\section{Thickness}

The thickness of the exposed part of the member is $2000 \mathrm{~m}$ on Nûgssuaq, where the formation includes the youngest pre-Quaternary rocks. Because of faulting the thickness was not evaluated on Hareøen.

\section{Lithology}

The member is dominated by 10-20 metre thick tholeiitic aa lavas with plagioclase as the dominant phenocryst mineral. On western Nûgssuaq the plagioclase phenocrysts are typically $1-10 \mathrm{~mm}$ long in the lower half of the member whereas microporphyritic basalts dominate in the upper half. On Hareøen a similar subdivision of the member has not been mapped although both lava types seem to be present (Hald, 1976). The tholeiitic lavas have higher concentrations of potassium (0.4-1.1\%), phosphorus, iron and titanium and lower concentrations of magnesium and calcium compared with the lavas of the Nûluk Member. Subalkaline, acid lavas and tuffs occur in subordinate amounts. On western Nûgssuaq thin anorthoclase-aenigmatite-hedenbergite porphyritic tuffs occur near the boundary between the porphyritic and microporphyritic subdivisions. 
Interbasaltic sediments are few. On western Nûgssuaq a sequence of arenaceous and argillaceous coal-bearing sediments up to $30 \mathrm{~m}$ thick is present which were formerly included in the Ifsorisok Formation by Koch (1963). The sediments occur locally $50 \mathrm{~m}$ below the peralkine tuffs, e.g. at the small river Puiagtùnguaq - a tributary to Itsatagdlip qôrua (Koch, 1964).

\section{Boundaries}

The lower boundary has been described above. On western Nûgssuaq the member comprises the youngest pre-Quaternary rocks exposed and consequently the upper boundary is unknown. Along the south coast of Hareøen lavas from the Kanísut Member are found near exposures of landslipped sediments belonging to the younger Hareøen Formation. Above Talerua at the north-east coast the member is overlain by olivine porphyritic basalts from Hareøen Formation with an angular unconformity.

\section{Distribution}

Western Nûgssuaq, except for smaller areas along the north and south coasts and along the west side of the Itivdle valley, consists of lavas belonging to the Kanísut Member. The member occupies most of the western and central parts of Hareøen; further exposures are found in small areas along the south coast.

\section{Hareøen Formation (Hald \& Pedersen, 1975)}

This formation is here divided into the older Aumarûtigssâ Member and the younger Talerua Member.

\section{Aumarûtigssâ Member \\ new member}

Sedimentary rocks from this member have been described by Giesecke in 1811 (Giesecke, 1910) and by Steenstrup (1883). They were included in the Ifsorisok Formation by Koch (1963).

\section{Name}

From Aumarûtigssâ on the north-east coast of Hareøen.

\section{Type area}

The sediments belonging to the Aumarûtigssâ Member are found only on the southeastern part of Hareøen, where they overlie the south-eastern limb of a broad anticline formed by lavas from the Nûluk and Kanísut Members.

The sediments are found in situ only in a gully above the south coast $5 \mathrm{~km}$ west' of Niaqua. The lower contact is not exposed and the sediments are overlain by Quaternary 
sediments. Elsewhere sediments from the Aumarûtigssâ Member are exposed in landslips along the south coast and the south-eastern part of the north-east coast, not including the promontory Niaqua.

\section{Thickness}

0 to more than $30 \mathrm{~m}$.

\section{Lithology}

Sandstone and mudstone - often of tuffaceous origin - are predominant. Coal seams are common, with retinite frequently occurring in the seams. Coarse grained conglomerates with basaltic pebbles are found.

\section{Boundaries}

As mentioned above neither the boundary with the lavas of the Kanísut Member below nor the boundary with the lavas from the Talerua Member above are exposed.

\section{Distribution}

The member has been found only in the southern part of Hareøen (except Niaqua). It is not known whether the limit of distribution towards the north-west is original or determined by erosion before eruption of the lavas from the Talerua Member.

\section{Talerua Member \\ new member}

Lavas from the member have been described by Pedersen (1970).

\section{Name}

From Talerua, a small point on the north-eastern coast of Hareøen.

Type area

South-eastern part of Hareøen.

\section{Thickness}

The maximum thickness exposed is $250 \mathrm{~m}$.

\section{Lithology}

Olivine porphyritic, transitional basalts enriched in potassium and alumina compared 
with the dominant olivine porphyritic lavas in the West Greenland Basalt Group. The flows are rarely more than $\mathbf{1 0} \mathrm{m}$ thick and the thinner flows in particular are strongly vesicular; horizontal, vesicular segregation veins are common.

\section{Boundaries}

The lavas transgress beyond the sediments of the older Aumarutigssâ Member (no depositional contacts exposed) and overlies plagioclase porphyritic lavas from the Kanísut Member with an angular unconformity above Talerua at the north-eastern coast. The Talerua Member represents the youngest pre-Quaternary rocks on Hareøen.

\section{Distribution}

South-eastern part of Hareøen except for the promontory Niaqua.

\section{References}

Clarke, D. B. \& Pedersen, A. K. 1976: Tertiary volcanic province of West Greenland. In Escher, A. \& Watt, W. S. (edit.) Geology of Greenland, 365-385. Copenhagen: Geol. Surv. Greenland.

Geological Survey of Greenland. 1974: Agatdal. 70 V. 1 Nord. 1:100 000.

Geological Survey of Greenland. 1976: Qutdligssat. 70 V. 1 Syd. 1:100 000.

Giesecke, K. L. 1910: Karl Ludwig Gieseckes mineralogisches Reisejournal über Grönland, 1806-1813. Meddr Grønland 35, 532 pp.

Hald, N. 1973: Preliminary results of the mapping of the Tertiary basalts in western Nûgssuaq. Rapp. Grønlands geol. Unders. 53, 11-19.

Hald, N. 1976: Early Tertiary flood basalt from Hareøen and western Nûgssuaq, West Greenland. Bull. Grønlands geol. Unders. 120, $36 \mathrm{pp}$.

Hald, N. \& Pedersen, A. K. 1975: Lithostratigraphy of the Early Tertiary volcanic rocks of central West Greenland. Rapp. Grønlands geol. Unders. 69, 17-24.

Henderson, G. 1969: Field work supplementing photogeological interpretation of Nûgssuaq. Rapp. Grønlands geol. Unders. 19, 18-21.

Koch, B. E. 1963: Fossil plants from the Lower Paleocene of the Agatdalen (Angmârtussut) area, central Nûgssuaq peninsula, Northwest Greenland. Bull. Grønlands geol. Unders. 38 (also Meddr Grønland 172,5) $120 \mathrm{pp}$.

Koch, B. E. 1964: Review of fossil floras and nonmarine deposits of West Greenland. Bull. geol. Soc. Amer. 75, 535-548.

Munck, S. \& Noe-Nygaard, A. 1957: Age determination of the various stages of the Tertiary volcanism in the west Greenland basalt province. 20th int. geol. Congr., Mexico, 1956 1, 247-256.

Münther, V. 1973: Results from a geological reconnaissance around Svartenhuk Halvø, West Greenland. Rapp. Grønlands geol. Unders. 50, $26 \mathrm{pp.}$

Nordenskiöld, A. E. 1871: Redogörelse för en Expedition till Grönland År 1870. Öfvers. VetenskAkad. Förh., Stockh. 27, 973-1082.

Pedersen, A. K. 1970: En petrologisk undersøgelse af tertiære vulkanske bjergarter fra det nordlige Disko. Unpublished prize dissertation, Univ. of Copenhagen. Reviewed in Festskrift Københavns Univ. 1970, 379-383.

Rosenkrantz, A. \& Pulvertaft, T. C. R. 1969: Cretaceous-Tertiary stratigraphy and tectonics in northern West Greenland. Mem. Am. Ass. Petrol. Geol. 12, 883-898.

Steenstrup, K. J. V. 1883: Om Forekomsten af Forsteninger i de kulførende Dannelser i Nord-Grønland. Meddr Grønland 5, 43-77. 